\title{
PREVALENCE OF FUSARIUM WILT OF TOMATO IN MAJOR TOMATO GROWING AREAS OF PUNJAB, PAKISTAN
}

\author{
aSalman Ahmad, aMaryam Yousaf, bRomana Anjum, aWaqas Raza, cMalik A. Rehman, dYasir Ali \\ a Department of Plant Pathology, College of Agriculture, University of Sargodha, Sargodha, Pakistan. \\ b Department of Plant Pathology, University of Agriculture, Faisalabad, Pakistan, \\ c Citrus Research Institute, Sargodha, Pakistan. \\ d College of Agriculture, Bahauddin Zakariya University, Bahadur Sub-campus, Layyah, Pakistan.
}

\section{ART I C L E I N F O}

\section{Article History}

Received: October 02, 2021

Revised: November 24, 2021

Accepted: December 10, 2021

\section{Keywords}

Disease severity

Fusarium oxysporum

Incidence

Lycopersicum esculentum

Prevalence

\section{A B S T R A C T}

Tomato is an essential vegetable in the world due to its nutritional importance. It has vitamin A \& C and lycopene, which reduce the prostate cancer, and heart and agerelated diseases. Tomato wilt disease (TWD) is a potential threat and spreading rapidly in tomato fields in Pakistan. The survey on the disease prevalence of Fusarium wilt (Fusarium oxysporum f.sp. lycopersici (Fol)) of tomato was conducted in the major tomato growing areas of Punjab, viz., Hafizabad, Pakpattan, Khushab, Sargodha and Faisalabad districts during the cropping season 2018. Tomato wilt disease incidence was higher in district Sargodha (94\%) followed by Faisalabad (92\%) and Khushab (65\%). Two districts, Pakpattan and Hafizabad showed $86 \%$ and $73 \%$ incidence, respectively. The survey revealed that tomato disease incidence was prevalent with varying intensities in all surveyed districts of Punjab. Moreover, the variation in disease prevalence of tomato wilt disease in different locations was due to the environmental conditions of that area and the varieties being cultivated.

Corresponding Author: Salman Ahmad

Email: salman.ahmad@uos.edu.pk

(C) The Author(s) 2021.

\section{INTRODUCTION}

Tomato (Lycopersicum esculentum Mill.) is a member of the family Solanaceae. It is originated from Peru, situated in South America. It is a precious horticultural crop for the market (Pritesh and Subramanian, 2011) and important due to its dietary components, which are contributing significantly to improve nutrition and health of both rural and urban populations (Waiganjo et al., 2006). Tomatoes are grown in all conditions, but give the best production in warm conditions where optimum temperatures are 15$30{ }^{\circ} \mathrm{C}$ (Hanaa et al., 2011). It is grown in both monsoon and winter Kharif and Rabi seasons (Nikhate, 2012). High humidity and temperatures reduce yields. While at the stage of ripening, temperature above $30{ }^{\circ} \mathrm{C}$ reduces the fruit yield.
Many factors can affect the yield and quality of tomato, among them; diseases play the most significant role (Pritesh and Subramanian, 2011). Commonly known diseases of tomato are early blight, anthracnose, bacterial wilt, bacterial canker, tomato spotted wilt, verticillium wilt and Fusarium wilt (Dodson et al., 2002). Tomato wilt disease (TWD) mainly caused tomato plant wilting, therefore referred as wilt disease. It is very important disease, either in field or greenhouse-grown tomatoes worldwide (Abdel-Fattah and Al-Amri, 2012; Amini and Sidovich, 2010; Sheu and Wang, 2006). The disease reaches at maximum level in tomato fields when wet conditions prevail on the fruit at maturity stage. Fusarium causes $20-80 \%$ losses per year worldwide (Nikhate, 2012). Characteristic symptoms of TWD are 
clearing of veins, leaves margins curling, leaves yellowing, stunting, development of adventitious roots, necrosis of blade of leaves, defoliation, and finally the whole plant died (Agrios, 1988; Srinivas et al., 2019).

Disease assessment of plant diseases is not an easy method (Ajilogba and Babalola, 2013). Plant diseases are assessed on the basis of different symptoms produced by plants after infections and disease assessment is vital for estimating the yield losses caused by different plant diseases, development of disease simulating models and and organizing surveys are the best strategies for the estimation of yield losses caused by different fungal pathogens (Campbell and Neher, 1994; Ghuffar et al., 2018). As per our best information, for the first time, the present study plans to record the prevalence of TWD in multiple districts of Punjab. During this study, comprehensive surveys were planned to generate large data set of incidence of tomato wilt disease (TWD). The surveys were conducted in major tomato growing areas of Punjab, viz., Hafizabad, Pakpattan, Sargodha, Khushab and Faisalabad, Pakistan, during the tomato cropping seasons of 2019-20.

\section{MATERIALS AND METHODS}

\section{Surveys and collection of diseased samples}

Surveys of most tomato wilt disease (TWD) affected districts of Province Punjab including Hafizabad, Pakpattan, Khushab, Sargodha and Faisalabad, Pakistan, was conducted in 2018 by using the GPS (GPS map76CSx, Garmin) tagging of these districts to determine the percent disease incidence (PDI) of TWD. The percent disease incidence of tomato wilt disease was determined by using following formula:

Disease Incidence $(\%)=\frac{\text { No. of tomato wilted plants }}{\text { Total number of tomato plants }} \times 100$

Data of percent disease incidence of TWD of each district was added in GPS and evaluated by ARCGIS and ARC View soft-wares to create the semi-variograms (Patel et al., 2016). Samples were collected from diseased tomato plants with typical symptoms and were placed in polythene zipper bags separately, labeled properly and stored in an ice box prior to isolations (Table 1).

Tomato plants were grown in plastic pots having sterilized soil in greenhouse at $28{ }^{\circ} \mathrm{C}$. Control of susceptible variety viz., Roma was also grown. Before inoculation, 2 to 3-week old plant roots were injured by repeatedly injecting a plastic peg into them. The inoculum, $1 \times 10^{9}$ spores $/ \mathrm{mL}$ at 2 -mL per pot, was drenched into the soil and allowed to penetrate into the rhizosphere. After fifteen days, symptoms were appeared (Fernández-García et al., 2012). Data was recorded every week according to the following disease assessment scale (Mir et al., 2011) (Table 2).

Table 1. Districts of Punjab where symptomatic tomato plants were collected.

\begin{tabular}{lc}
\hline Districts of Punjab & Number of samples \\
\hline Sargodha & 50 \\
Khushab & 20 \\
Pakpattan & 60 \\
Faisalabad & 50 \\
Hafizabad & 30 \\
Total & 210 \\
\hline
\end{tabular}

Table 2. Disease assessment scale used for tomato wilt disease (TWD).

\begin{tabular}{cc}
\hline Rating scale & Percent Severity \\
\hline 0 & No symptoms \\
1 & $1-10 \%$ plant area infected \\
2 & $11-20 \%$ plant area infected \\
3 & $21-30 \%$ plant area infected \\
4 & $31-40 \%$ plant area infected \\
5 & $41-50 \%$ plant area infected \\
6 & $51-60 \%$ plant area infected \\
7 & $>61 \%$ plant area infected \\
\hline
\end{tabular}

Source: Aslam et al. (2017)

Disease incidence (\%) was calculated using following formula;

Disease Incidence (\%)

\section{Statistical analysis}

$$
=\frac{\text { No. of diseased plants }}{\text { Total plants }} \times 100
$$

Disease incidence data was analyzed statistically using SAS (SAS Institute, NC, USA 1990). Analysis of variance (ANOVA) was used to test the main and interaction effects of the treatments. To check the effects of each treatment, means of each treatment were compared using LSD test at $5 \%$ level of significance (Steel et al., 1996).

\section{RESULTS}

For the spatio-variation, the selected five districts of Punjab such as Sargodha, Faisalabad, Pakpattan, Hafizabad, and Khushab were highly affected with TWD. In surveys of five districts in Punjab, semi-variograms 
were created that mapped disease incidence ratings as follows: green (0-20\% severity), light green (21-40\%), yellowish-green (41-60\%), yellow (61-80\%), orange red (81-90\%) and red (91-100\%). Faisalabad semivariograms showed in Figure 1, Hifazabad semi-

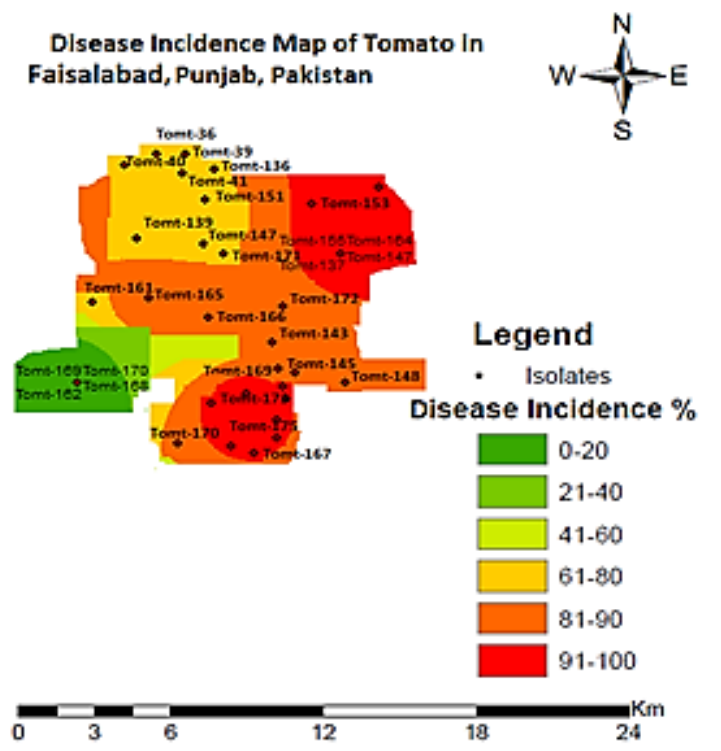

Figure 1. Map of incidence of tomato wilt caused by Fol in Faisalabad district.

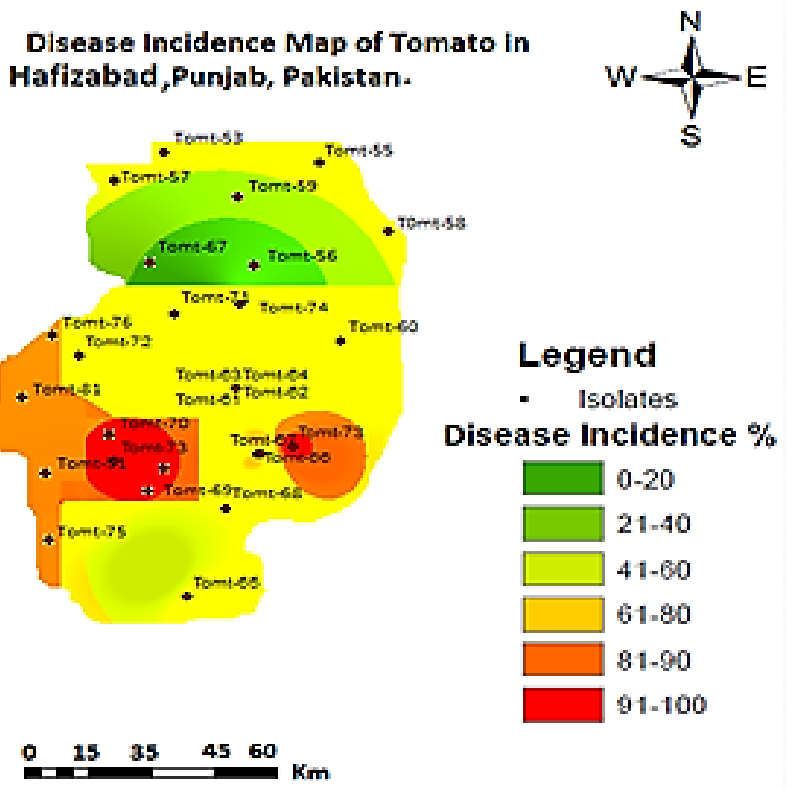

Figure 3. Map of incidence of tomato wilt caused by Fol in Hifzabad district

Spatial variation within and among districts showed highest incidence in Sargodha 94\% followed by Faisalabad 92\%, Pakpattan 82\%, Hafizabad 65\% and Khushab 73\%, respectively. On the bases of semi- variograms showed in Figure 3, Khushab semivariograms showed in Figure 2, Sargodha semivariograms showed in Figure 4 while Pakpattan semivariograms showed in Figure 5.

Disease Incidence Map of Tomato in
Khushab, Punjab, Pakistan<smiles></smiles>

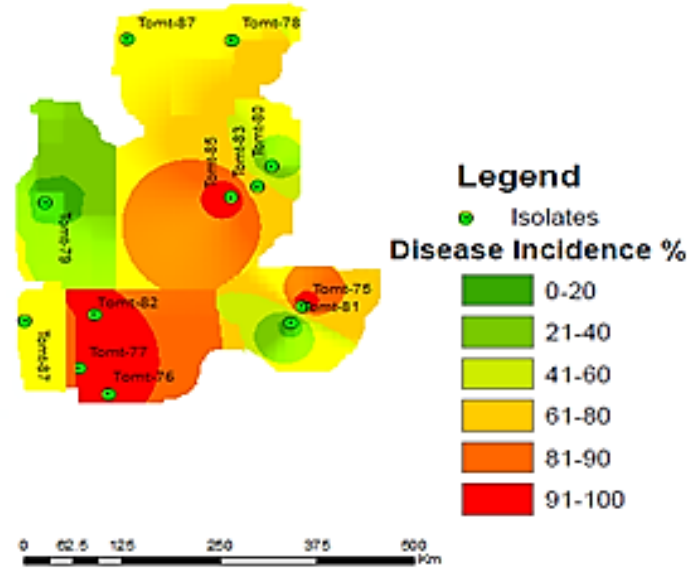

Figure 2. Map of incidence of tomato wilt caused by Fol in Khushab district.

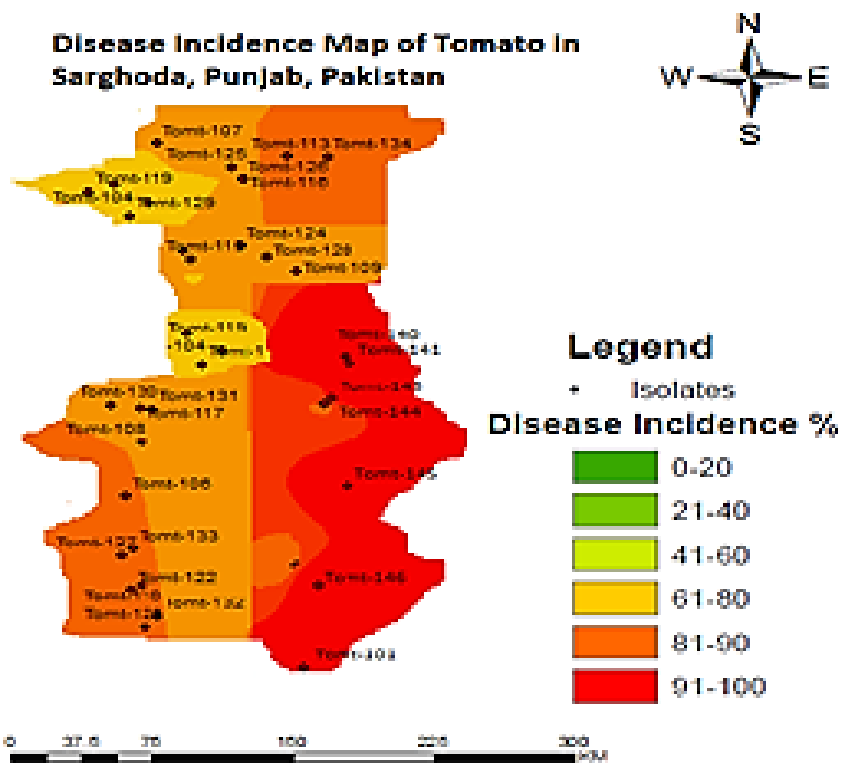

Figure 4. Map of incidence of tomato wilt caused by Fol in Sargodha district

variograms, it was concluded that Sargodha and Faisalabad had the most severe outbreaks of Fusarium wilt (Figure 1-4). 


\section{DISCUSSION}

For the effective management of crop diseases, their assessment is vital (Campbell and Neher, 1994). Meteorological variables suitable for TWD development are relative humidity, temperature, intervals of leaf wetness and precipitation. Temperature 17 to $22^{\circ} \mathrm{C}$ with $90 \%$ relative humidity is considered most suitable for TWD (Modesto et al., 2016).

TWD caused by soil-borne fungus Fol is a major cause of yield losses in warm-temperate to tropical latitudes worldwide (Dodson et al., 2002). This disease causes wilting of the whole plant by entering from the roots and spreading via xylem fibers, blocking the movement of water (Cox et al., 2019). In this study, a survey of tomato wilt on farms was conducted in different areas of Punjab including Sargodha, Faisalabad, Pakpattan, Hafizabad, and Khushab. This survey revealed that fields in Sargodha had 94\% incidence of tomato wilt, followed by Faisalabad (92\%), Pakpattan (86\%), Hafizabad (73\%), and Khushab (65\%). These results are in line with the findings of Heydari et al. (2007) and McGovern (2015). They reported 100\% incidence of TWD in USA. Houterman et al. (2007) reported less prevalence of TWD on resistant cultivars, i.e., 0-29\%, while $100 \%$ on susceptible cultivars in USA. AbdelFattah and Al-Amri (2012) reported 53-71\% disease incidence while 47-78\% disease severity of TWD in Egypt. Ishikawa et al. (2005) reported 50\% disease severity in Japan, while Mandal et al. (2009) reported $40 \%$ TWD incidence in Japan in those fields where recommended foliar sprays of fungicides were applied. TWD is very notorious and has been reported in different countries even after the routine fungicidal applications, Iran 31-48\%, Greece 45\%, Thailand 80\% and India 42\% (Myresiotis et al., 2012).

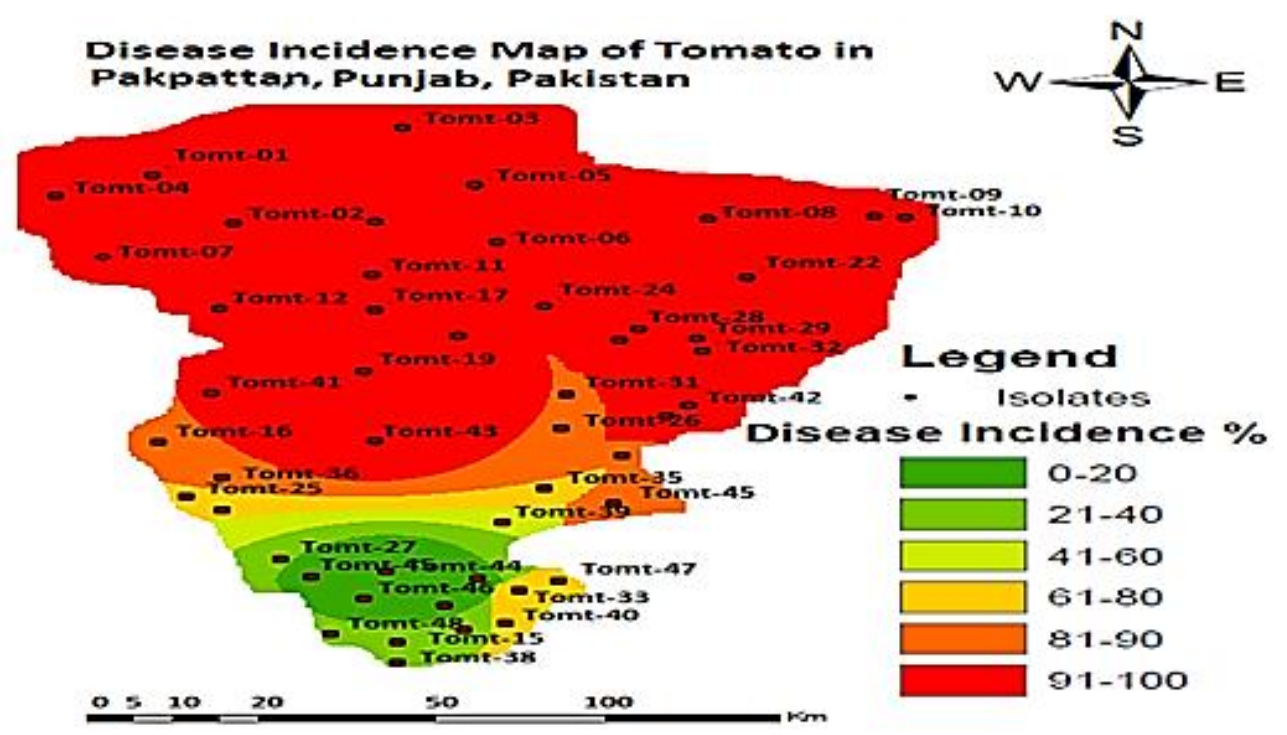

Figure 5. Map of incidence of tomato wilt caused by Fol in Pakpattan district.

The survey noted tomato wilt symptoms including yellowing of leaves, disappearance of veins from the leaves, stunting, curling of leaves, emergence of new adventitious roots, defoliation of leaves, drying of stem and roots, and finally plant collapses and becomes dead (Agrios, 1988). These symptoms have also been reported in previous investigation (Fassihiani, 2000). Fol has the ability to produce the same symptoms in other Solanum spp. including $S$. pimpinellifolium and $S$. melogena (Fassihiani, 2000). There are hosts which carry Fol but do not produce symptoms; includes
Chenopodium, Amaranthus, Malva, Digitaria and Oryzopsis spp. (Fassihiani, 2000). There are reports that legumes are very susceptible to Fol and show the same symptoms as observed on tomato (McGovern, 2015). Chlymadospores of $\mathrm{Fol}$ cause more severe symptoms in tomatoes than the macro- and micro conidia (McGovern, 2015). Fusarium spp. are versatile fungi that can survive on dead as well as living organic matter and persist in soil for years in the absence of host plants (Gordon, 2017). Fusarium spp. pervasive soil-borne pathogens that cause many diseases in horticulture and agronomic 
crops, including rots, vascular wilts, and damping-off (Bodah, 2017). Fol is a soil-inhabiting fungus having phylogenetic diversity (Xiong and Zhan, 2018). Warm weather, applications of ammonium containing fertilizers and low $\mathrm{pH}$ of soil exacerbate the symptoms of TWD (McGovern, 2015).

Results from the current survey provided evidence of the prevalence and crop damage caused by tomato wilt in Punjab Province. This disease can undermine farm sustainability and rural livelihoods in Punjab, so it merits more intensive study in order to develop costeffective ways to reduce economic losses.

\section{ACKNOWLEDGEMENTS}

The authors are thankful to the support provided by Department of Plant Pathology, University of Agriculture, Faisalabad.

\section{REFERENCES}

Abdel-Fattah, G. and S. Al-Amri. 2012. Induced systemic resistance in tomato plants against Fusarium oxysporum f.sp. lycopersici by different kinds of compost. African Journal of Biotechnology, 11: 12454-63.

Agrios, G. 1988. Studied the symptoms of Fusarium oxysporum. In, Plant Pathology. Acdemic Press, Inc. New York, USA.

Ajilogba, C. F. and 0. O. Babalola. 2013. Integrated management strategies for tomato Fusarium wilt. Biocontrol science, 18: 117-27.

Amini, J. and D. Sidovich. 2010. The effects of fungicides on Fusarium oxysporum f. sp. lycopersici associated with Fusarium wilt of tomato. Journal of plant protection research, 50: 175-83.

Aslam, M. N., T. Mukhtar, M. A. Hussain and M. Raheel. 2017. Assessment of resistance to bacterial wilt incited by Ralstonia solanacearum in tomato germplasm. Journal of Plant Diseases and Protection, 124: 585-90.

Bodah, E. T. 2017. Root rot diseases in plants: A review of common causal agents and management strategies. Agricultural Research and Technology: Open Access Journal, 5: 555661.

Campbell, C. L. and D. Neher. 1994. Estimating disease severity and incidence. In, Epidemiology and Management of Root Diseases. Springer. Berlin, Germany.

Cox, K. L., K. Babilonia, T. Wheeler, P. He and L. Shan.
2019. Return of old foes-recurrence of bacterial blight and Fusarium wilt of cotton. Current opinion in plant biology, 50: 95-103.

Dodson, M., P. Williams and J. Bachmann. 2002. Organic Greenhouse Tomato Production. ATTRA: Fayetteville.

Fassihiani, A. 2000. Symptomless carriers of the causal agent of tomato wilt pathogen. Journal of Agricultural Science and Technology, 2.

Fernández-García, E., I. Carvajal-Lérida, M. Jarén-Galán, J. Garrido-Fernández, A. Pérez-Gálvez and D. Hornero-Méndez. 2012. Carotenoids bioavailability from foods: From plant pigments to efficient biological activities. Food Research International, 46: 438-50.

Ghuffar, S., G. Irshad, F. Zhai, A. Aziz, H. M. A. M. Asadullah, N. Mehmood, H. Yang, A. Bashir, M. Z. Ahmed and M. F. Aslam. 2018. First report of Fusarium proliferatum causing fruit rot of grapes (Vitis vinifera) in Pakistan. International Journal of Phytopathology, 7: 85-88.

Gordon, T. R. 2017. Fusarium oxysporum and the Fusarium wilt syndrome. Annual review of phytopathology, 55: 23-39.

Hanaa, R. F., Z. A. Abdou, D. A. Salama, M. A. Ibrahim and H. Sror. 2011. Effect of neem and willow aqueous extracts on Fusarium wilt disease in tomato seedlings: Induction of antioxidant defensive enzymes. Annals of Agricultural Sciences, 56: 1-7.

Heydari, A., I. Misaghi and G. Balestra. 2007. Preemergence herbicides influence the efficacy of fungicides in controlling cotton seedling dampingoff in the field. International Journal of Agricultural Research, 2: 1049-53.

Houterman, P. M., D. Speijer, H. L. Dekker, C. G. de Koster, B. J. Cornelissen and M. Rep. 2007. The mixed xylem sap proteome of Fusarium oxysporum infected tomato plants. Molecular plant pathology, 8: 215-21.

Ishikawa, R., K. Shirouzu, H. Nakashita, H.-Y. Lee, T. Motoyama, I. Yamaguchi, T. Teraoka and T. Arie. 2005. Foliar spray of validamycin A or validoxylamine A controls tomato Fusarium wilt. Phytopathology, 95: 1209-16.

Mandal, S., N. Mallick and A. Mitra. 2009. Salicylic acidinduced resistance to Fusarium oxysporum f. sp. lycopersici in tomato. Plant physiology and Biochemistry, 47: 642-49. 
McGovern, R. 2015. Management of tomato diseases caused by Fusarium oxysporum. Crop Protection, 73: 78-92.

Mir, R. A., A. H. Wani, M. Y. Bhat, T. Un-Nisa and S. A. Pala. 2011. Incidence and intensity of powdery mildew fungi on the plants of papilionaceae. New York Science Journal, 4: 14-20.

Modesto, O. O., M. Anwar, Z. He, R. P. Larkin and C. W. Honeycutt. 2016. Survival potential of Phytophthora infestans sporangia in relation to environmental factors and late blight occurrence. Journal of plant protection research, 56: 73-81.

Myresiotis, C. K., G. S. Karaoglanidis, Z. Vryzas and E. Papadopoulou-Mourkidou. 2012. Evaluation of plant-growth-promoting rhizobacteria, acibenzolar-S-methyl and hymexazol for integrated control of Fusarium crown and root rot on tomato. Pest management science, 68: 404-11.

Nikhate. 2012. Studies on wilt of tomato caused by Fusarium oxysporum f.sp. lycopersici, M. P. K. V. Rahuri.

Patel, A., S. Katiyar and V. Prasad. 2016. Performances evaluation of different open source DEM using differential global positioning system (DGPS). The Egyptian Journal of Remote Sensing and Space Science, 19: 7-16.

Pritesh, P. and R. Subramanian. 2011. PCR based method for testing Fusarium wilt resistance of tomato. African Journal of Basic and Applied Sciences, 3: 222-38.

Sheu, Z. and T. Wang. 2006. First report of Race 2 of Fusarium oxysporum f. sp. lycopersici, the causal agent of fusarium wilt on tomato in Taiwan. Plant Disease, 90: 111-11.

Srinivas, C., D. N. Devi, K. N. Murthy, C. D. Mohan, T. Lakshmeesha, B. Singh, N. K. Kalagatur, S. Niranjana, A. Hashem and A. A. Alqarawi. 2019. Fusarium oxysporum f. sp. lycopersici causal agent of vascular wilt disease of tomato: Biology to diversity: A review. Saudi journal of biological sciences, 26: 1315-24.

Steel, R., J. Torrie and D. Dickey. 1996. Principles and Procedures of Statistics: A Biometrical Approach. McGraw Hill Book Company Inc: New York, USA.

Waiganjo, M., N. Wabule, D. Nyongesa, J. Kibaki, I. Onyango, S. Wepukhulu and N. Muthoka. 2006. Tomato production in Kirinyaga district, Kenya, a baseline survey report. Kenya Agricultural Research Institute. Nairobi, Kenya, pp. 1-43.

Xiong, W. and A. Zhan. 2018. Testing clustering strategies for metabarcoding-based investigation of community, environment interactions. Molecular Ecology Resources, 18: 1326-38.

\section{CONFLICT OF INTEREST}

The authors have not declared any conflict of interests.

\section{AUTHORS CONTRIBUTIONS}

Salman Ahmad and Romana Anjum supervised the research; Maryam Yousaf conducted research; Waqas Raza helped in manuscript drafting; Malik A. Rehman, Yasir Ali helped in analyzing the data.

Publisher's note: EScience Press remains neutral with regard to jurisdictional claims in published maps and institutional affiliations.

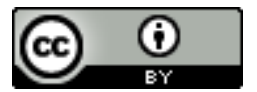

Open Access This article is licensed under a Creative Commons Attribution 4.0 International License, which permits use, sharing, adaptation, distribution and reproduction in any medium or format, as long as you give appropriate credit to the original author(s) and the source, provide a link to the Creative Commons license and indicate if changes were made. The images or other third-party material in this article are included in the article's Creative Commons license, unless indicated otherwise in a credit line to the material. If material is not included in the article's Creative Commons license and your intended use is not permitted by statutory regulation or exceeds the permitted use, you will need to obtain permission directly from the copyright holder. To view a copy of this license, visit http://creativecommons.org/licenses/by/4.0/. 